might actually be due to socio-economic or cultural factors that just happen to correlate with race.

Risch also argues that minority groups should be selectively recruited into biomedical studies to ensure that they are sufficiently well represented to reveal any important differences from the population as a whole. Take a race-neutral approach, says Risch, and important information about minority health maybe lost.

Not surprisingly, some scientists take issue with Risch's arguments. Harold Freeman, a prominent African-American researcher who is director of the National Cancer Institute's Center to Reduce Cancer Health Disparities, based in Rockville, Maryland, agrees that cultural factors should be considered in genetic studies. But he argues that racial labels are too crude to be useful. "Culture is not equal to race," says Freeman.

Worse, Freeman fears that the use of race as a variable in biomedical studies will perpetuate historical discriminatory attitudes. He adds that statistical findings from population-genetic studies may be wrongly applied to racial groups as a whole. If a drug is found to work less well in African Americans than in Caucasians, for example, it may end up being denied to individuals within the black population who might nevertheless benefit from it.

Goldstein worries that the tone of the Risch paper will bring unwanted political overtones into what ought to be a technical discussion. He accepts that it can be useful to divide populations into subgroups that reflect the geographical origins of their members' ancestors. However, Goldstein says that "race is not a terribly good framework. I believe we can do better. This is a technical question. I think that Neil has politicized it too much."

Risch argues that his article is merely responding to statements made in the scientific literature by other commentators. For instance, an editorial in The New England Journal of Medicine last year argued that "race is biologically meaningless" (see R. S. Schwartz N. Engl. J. Med. 344, 1392-1393; 2001).

Francis Collins, director of the Nationa Human Genome Research Institute in Bethesda, Maryland, feels that Risch makes some valid points. He points out that the international 'haplotype map' project, an effort to discover disease-susceptibility genes (see Nature 412, 105; 2001), includes DNA samples from the main geographical areas of the world. But Collins thinks that Risch was unwise to frame the issue in terms of racial labels. "It's open to broad misinterpretation," he says. "I'd be happier if we could get away from the highly charged terminology of race and refer instead to geographical origin of ancestors."

\title{
Bioethics council demands tighter rules on gene patents
}

\section{David Adam, London}

Patents on DNA sequences are granted too easily, too often and with too little scrutiny, says an investigation into gene patenting by Britain's foremost bioethics body.

Thousands of recent patents asserting rights over DNA sequences are of "doubtful validity", according to a report released on 23 July by the Nuffield Council on Bioethics. The report says that, in future, patents involving DNA sequences should be issued as an exception, not as a rule.

Sandy Thomas, director of the council which is operated and funded by the UK government's Medical Research Council and two London-based charities, the Wellcome Trust and the Nuffield Foundation — says the assessment is the broadest attempt yet to take stock of gene patenting after what she terms the "gold rush" that followed the publication of the human genome sequence last year.

"We are concerned that, for patents involving DNA, the patent system is in danger of not achieving its main goal: to stimulate innovation for the public good," Thomas says. Technology that allows computer users to identify genes and then patent them by merely sifting published sequences makes a mockery of the idea that applicants should demonstrate "inventiveness", she argues.

Previously, researchers had to identify, isolate and clone a gene before deciphering its sequence. "We're talking about a reassessment of the system," Thomas says, "not just a little bit of tightening here and there."

The report's authors hope their work will help to inform the decision-making processes of patent offices around the world. Some fear that existing patent regimes are too heavily influenced by pressure from patent applicants and their employers, and are not responsive enough to the interests of other researchers, who want open access to gene sequences, or of society as a whole.

To obtain a patent, applicants must convince patent offices that their innovation is not only novel and inventive, but also useful. The Nuffield report argues that, in many cases, the rigorous application of these existing criteria would reduce the number of gene patents issued, without any new rules.

The world's three largest patent systems, in Japan, Europe and the United States, currently treat each criterion differently. The US patent office is generally the most relaxed in issuing patents that involve DNA sequences, although it has tightened its scrutiny of utility in response to criticism that it was awarding patents on sequences with unproven or purely speculative uses (see Nature 403, 3; 2000).

Rainer Moufang, a patent lawyer with the

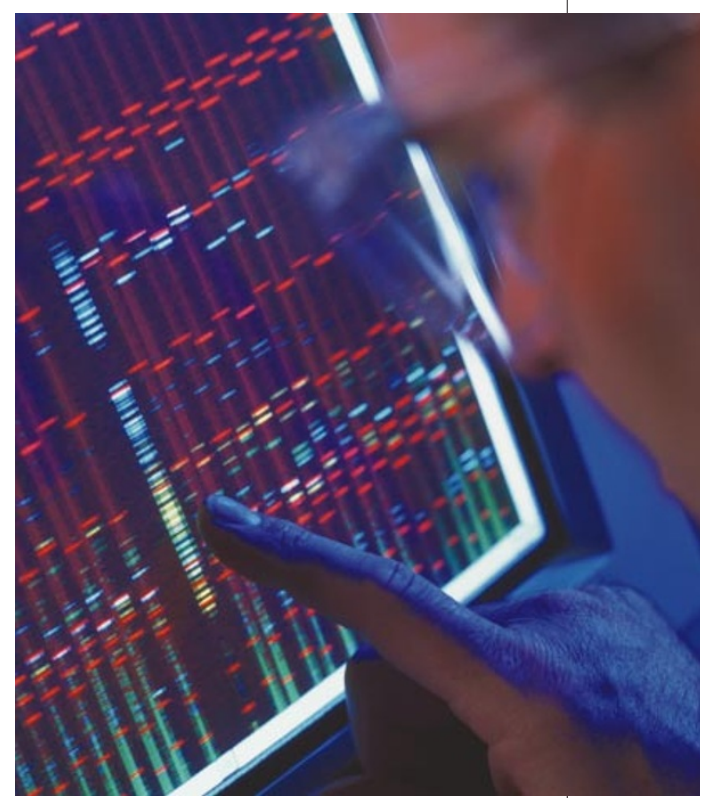

Market speculation: has the availability of the human gene sequence led to a gold rush?

European Patent Office in Munich, says that European regulations have also been tightened and that applicants must show a commercial application before a patent is granted. The report's conclusion that patents on DNA should be the exception rather than the rule is "rather a difficult prognosis", says Moufang. "For us to change our practice we would need a clear hint from legislators," he adds.

Applications for patents on gene sequences that could be used to diagnose diseases should receive particular scrutiny, the report says. It contends, for example, that patents held by the US company Myriad Genetics on the BRCA1 gene, which is linked to susceptibility to breast cancer, give the company effective control over the sequence, stopping others from developing alternative diagnostic tests. Some of Myriad's European patents are being challenged by French researchers (see Nature 413, 95; 2001).

Deryck Beyleveld, director of the Sheffield Institute of Biotechnological Law and Ethics at Sheffield University, UK, welcomes the report's suggestions. "They are workable in both principle and practice," he says. "The obstacles will appear when they run into the politics."

Political leaders associate patents with competitiveness, says Beyleveld, and will be reluctant to discourage gene patenting. "We no longer have a patent system that rewards inventors for their creativity," he claims, "but one that essentially rewards investors for their investment." 